\title{
Physicochemical Parameters Of Effluents From A Lubricating Oil Company And Metal Analysis Of The Sediment Of The Receiving Stream In Osogbo Osun State, Nigeria
}

\author{
Adeniji, Ayodeji Oluwole ${ }^{1}$, Olabanji, lyabo Oluremi*2, Oluyemi, Emmanuel Ayodele ${ }^{3}$ \\ ${ }^{1}$ Department of Chemistry, Obafemi Awolowo University, Ile-Ife, Nigeria. \\ adeniji.ayodeji@yahoo.com \\ 2 Department of Chemistry, Obafemi Awolowo University, Ile-Ife, Nigeria. \\ ioolabanji@yahoo.com \\ ${ }^{3}$ Department of Chemistry, Obafemi Awolowo University, Ile-Ife, Nigeria. \\ ayodele_oluyemi@yahoo.co.uk
}

\begin{abstract}
Effluent and its receiving sediment samples were collected on seasonal basis, comprising of three months (August to October, 2014) in the wet season and three months (December 2014 to February 2015) in the dry season. Five sampling points around the lubricating oil company were marked for the study. Physicochemical parameters of the effluent samples such as $\mathrm{pH}$, temperature, conductivity, total dissolve solids were determined in situ. Dissolved oxygen and biochemical oxygen demand were determined by Winkler's method. Digestion of the sediments was carried out by acid dissolution. The heavy metals ( $\mathrm{Mn}, \mathrm{Ni}, \mathrm{Co}, \mathrm{Cd}$ and $\mathrm{Pb}$ ) level was determined using Flame Atomic Absorption Spectrophotometer. The results revealed that the physicochemical parameters ranged between $\left(27.40\right.$ to $\left.29.86^{\circ} \mathrm{C}\right)$ for temperature, $\mathrm{pH}$ (6.89 to 7.88$)$, electrical conductivity $(92.27$ to $292.84 \mu \mathrm{s} / \mathrm{cm})$, total dissolve solids, dissolved oxygen (2.58 to $7.01 \mathrm{mg} / \mathrm{L})$, biochemical oxygen demand $(5.00$ to $14.00 \mathrm{mg} / \mathrm{L})$ for the sampling periods. The overall total metal was in similar order: $\mathrm{Mn}>\mathrm{Ni}>\mathrm{Co}>\mathrm{Cd}>\mathrm{Pb}$ for both seasons. Most of the results were within the recommended limit required except for the levels of biochemical oxygen demand which exceeded the recommended value of $10 \mathrm{mg} / \mathrm{L}$ in dry season by WHO, (2006). Statistically, no significant difference at $p \leq 0.05$ between the parameters obtained in both seasons. The study concluded that the effluents discharged from the lubricating oil company in osogbo was polluted based on the results of biochemical oxygen demand and the Cd concentrations in the sediment samples.
\end{abstract}

\section{Keywords}

Heavy metals; Sediments; Effluents; Dissolved oxygen; Biochemical oxygen.

\section{Academic Discipline and Sub-Disciplines}

Environmental Chemistry and Analytical Chemistry

\section{SUBJECT CLASSIFICATION}

Quantification of heavy metals in effluent and sediment

\section{TYPE (METHOD/APPROACH)}

Wet Chemistry and Instrumental Analysis

\section{INRODUCTION}

Petrochemical plants generate solid waste and sludge composed of organic, inorganic compounds including heavy metals [1]. According to Lenntech heavy metals are chemical elements of relatively high densities [2]. Heavy metals are released into the environment: water, soil and air through activities like agriculture, power generation, industrial discharges, seepage of municipal landfills, septic tank effluents. Many authors have reported high levels of heavy metal ions in the soil, rivers and groundwater in different areas of Nigeria [3]. To save the environment from further deterioration and also maintain sound public health, many methods have been developed as reported by the use of organic material such as solid waste, agricultural waste and industrial waste [4].

There are many ways by which heavy metals associate with soil/sediment components and it can be determine to know their mobility and availability. The determination of total content of heavy metals is one of the useful methods for the characterization of pollution intensity of the heavy metal in the soil [5].

This study is aimed to carrying out physicochemical analysis of effluents and its metal pollution on the soil upon discharged from a lubricating oil company in Osogbo with a view to revealing the pollution status of the studied area.

\section{MATERIALS AND METHODS \\ Reagents Used and Their Sources}

The reagents used were of analytical grades and they include: $\mathrm{HNO}_{3}$ (Riedel-deHaen, Germany), $\mathrm{HCl}$ (SigmaAldrich, Germany), HF (British Drug House (BDH) Chemicals Ltd, Poole, England. 


\section{Sample Collection and Pre-treatment}

Samples were collected from five different sites around the lubricating oil company in Osogbo in wet (August, September, October) and dry season (December, January, February) respectively. The geographical locations of these sites were determined using GPS-Magellian GPS 3010. The map of the study area (Figure 1) depicts the sampling sites in Osogbo Osun State in Nigeria.

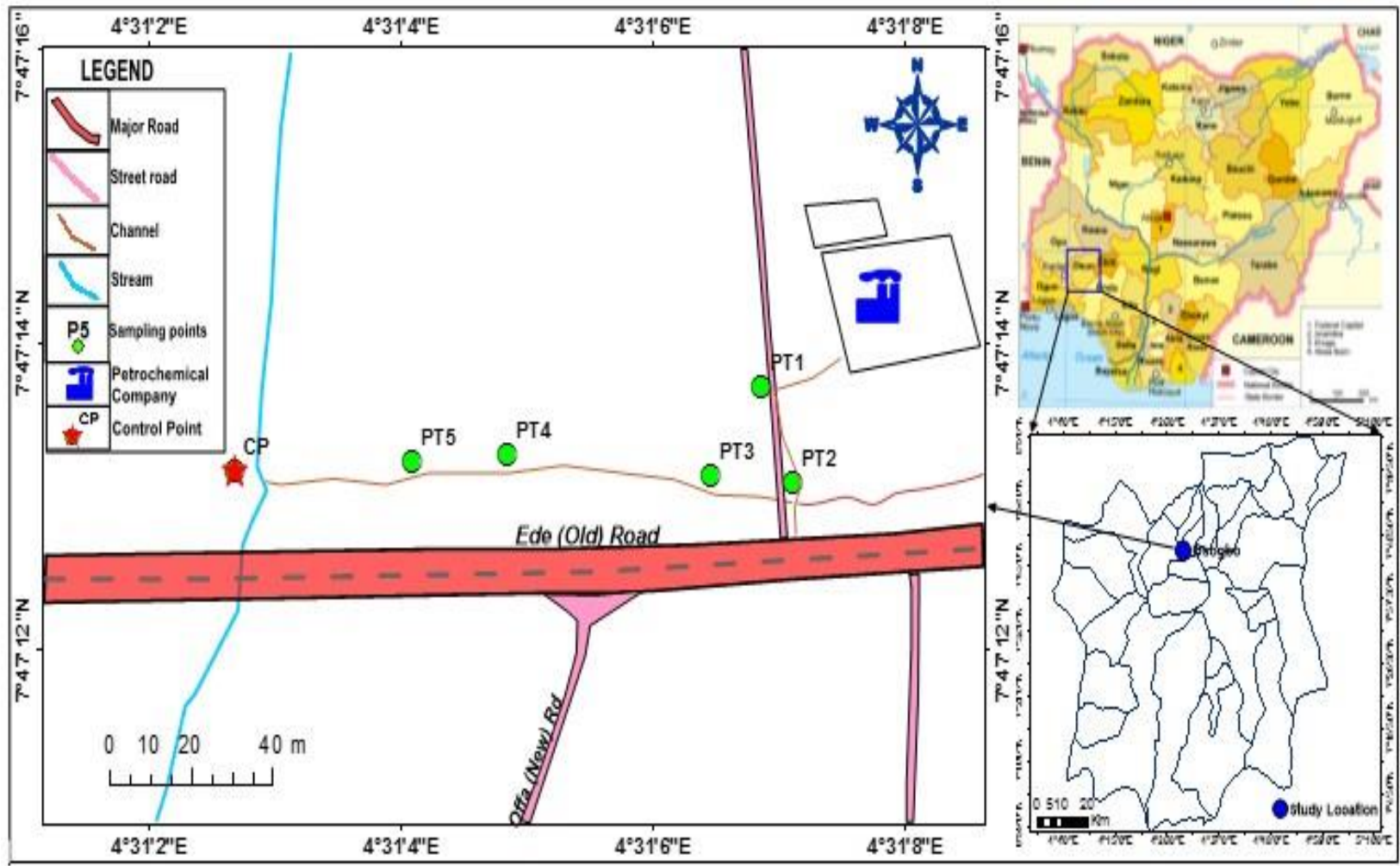

Figure 1 The locations of the sampling sites in Osogbo

Sample collection containers ( $1 \mathrm{~L}$ capacity treated polyethylene bottles) were rinsed three times with effluent at the sampling sites before sample collection. Water temperatures, electrical conductivity (EC), total dissolved solid (TDS) as well as $\mathrm{pH}$ values were measured using Hanna Model H198107 according to standard analytical methods at the point of collection and the samples were transported to the laboratory. The effluent was allowed to settle and the clear water was carefully decanted. The soil sediment samples were air dried and powdered using an agate mortar and pestle. Dissolve oxygen (DO) was determined by azide modification method. Biochemical Oxygen Demand (BOD) by 5 days incubation method.

\section{Determination of Total Metal Concentration in Sediment Samples}

One gram of the soil sediment sample was digested with $30 \mathrm{~mL}$ aqua regia $\left(\mathrm{HC}_{1}: \mathrm{HNO}_{3} ; 3: 1\right)$ on a thermostated hot plate at a temperature between $150^{\circ} \mathrm{C}$ and $180^{\circ} \mathrm{C}$. The contents of the Teflon beaker were replenished with more aqua regia to avoid total evaporation. After approximately two hours of digestion, $5 \mathrm{~mL} \mathrm{HF}$ was added to the Teflon beaker and the temperature of the hot plate was decreased to induce simmering. The sample was digested further for 30 minutes. The Teflon beaker containing the sample was allowed to cool at room temperature before it was quantitatively transferred into a $25 \mathrm{~mL}$ volumetric flask and filled to the mark with twice distilled water. A blank determination was carried out using same procedure. Concentrations of $\mathrm{Mn}, \mathrm{Ni}, \mathrm{Co}, \mathrm{Cd}$ and $\mathrm{Pb}$ were determined by Atomic Absorption Spectrophotometry at the Centre for Energy Research and Development (CERD), Obafemi Awolowo University, Ile-Ife, Nigeria.

\section{Contamination Assessment of Sediment Samples}

The geo-accumulation index (I-geo) values were calculated for all the metals to know the level of contamination as introduced by Muller according to the following expression:

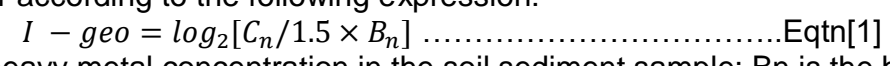

where $\mathrm{Cn}$ is the total heavy metal concentration in the soil sediment sample; $\mathrm{Bn}$ is the background value in unpolluted sample; and 1.5 is the background matrix correction factor introduced to minimize variations of heavy metals due to lithogenic effects [6].

The I-geo values are classified into seven $(0-6)$ classes: Class 0 is when I-geo $<0$ ( Practically unpolluted, PU, samples); Class 1 is when $0<\mathrm{I}$-geo $<1$ ( Practically unpolluted to moderately polluted, MP, samples); Class 2 is when $1<$ $\mathrm{I}$-geo $<2$ (moderately polluted, MP, samples); Class 3 is when $2<\mathrm{I}$-geo $<3$ (moderately polluted, MP, to heavily Polluted, 


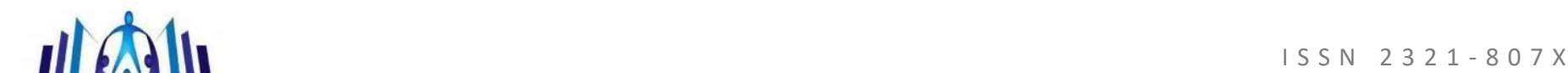

HP, samples); Class 4 is when $3<\mathrm{I}$-geo $<4$ (heavily polluted, HP, samples); Class 5 is when $4<\mathrm{I}$-geo $<5$ (heavily polluted to very heavily polluted, VHP, samples); Class 6 is when $5<\mathrm{I}$-geo $<6$ (very heavily polluted, VHP, samples). The background values of $320,17,10,0.3$ and $17 \mu \mathrm{g} / \mathrm{g}$ for unpolluted soils [7] for $\mathrm{Mn}, \mathrm{Ni}, \mathrm{Co}$, Cd and $\mathrm{Pb}$ respectively were used against the mean total heavy metals in the soil sediments.

\section{Determination of Pollution Load Index (PLI)}

The pollution load index was calculated for different metals as introduced by Thomlinson [8] as follows; PLI =

$$
\begin{gathered}
\left(\mathrm{CF}_{1 \times} \times \mathrm{CF}_{2 \times} \mathrm{CF}_{3} \times \ldots \ldots \mathrm{CF}_{n}\right)^{1 / n} \ldots \ldots \ldots \ldots \ldots \ldots \ldots \ldots \ldots \ldots \ldots \ldots \ldots \\
\mathrm{CF}=\mathrm{C} \times / \mathrm{Bn}
\end{gathered}
$$

$\mathrm{CF}=$ Contamination factor; $\mathrm{Bn}=$ Background value of the element in the shale or rock; $\mathrm{Cx}=$ Total heavy metal concentration in the sediment sample of each element.

$\mathrm{PLI}<1$ denote perfection; $\mathrm{PLI}=$ only baseline levels of pollutants are presented and $\mathrm{PLI}>1$ indicate deterioration of site quality. The background values of $320,17,10,0.3$ and $17 \mu \mathrm{g} / \mathrm{g}$ for shale or rock [9] for $\mathrm{Mn}, \mathrm{Ni}, \mathrm{Co}, \mathrm{Cd}$ and $\mathrm{Pb}$ respectively

\section{Enrichment Factor (EF)} were used.

Enrichment factor was calculated as introduced by Sutherland [10] as follows;

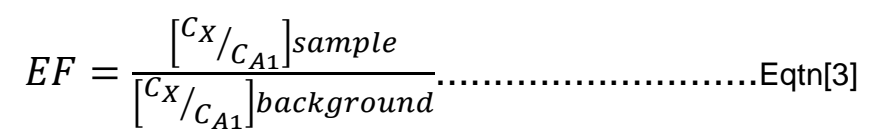

sample and $\left[\mathrm{CX} / \mathrm{C}_{\mathrm{A} 1}\right]$ background is the reference ratio in the background. The background values were taken from average shale $[6,9,11]$ and aluminium (the reference value being $8.0 \mu \mathrm{g} / \mathrm{g}$ ) was selected as the reference element, due to its crustal dominance and its high immobility [12]. Five contamination categories are recognized on the basis of enrichment factor as follows: $E F<2$ : Deficient to minimal enrichment; $2 \leq \mathrm{EF}<5$ : Moderate enrichment; $5 \leq \mathrm{EF}<20$ : Significant enrichment; $20 \leq E F<40$ : Very high enrichment; EF $\geq 40$ : Extremely high enrichment. As the EF values increase, the contributions of the anthropogenic origins also increase [10].

\section{Statistical Analysis}

All data obtained were subjected to descriptive statistical analysis (95\% confidence limit). The statistical package for social sciences (SPSS) was used for computation to determine the mean, standard deviation, Pearson's correlation coefficient.

\section{RESULTS AND DISCUSSION}

Table 1 present the geographical locations of the sampling sites. The study area lies within longitudes $4 \circ 31$ '0.41"

\begin{tabular}{|c|c|c|c|}
\hline \multirow[t]{2}{*}{ Sampling site } & \multirow[t]{2}{*}{ Elevation (m) } & \multicolumn{2}{|l|}{ GPS Values } \\
\hline & & Latitude $(\mathrm{N})$ & Longitude (E) \\
\hline Point 1 & 66.96 & 747'13.7"' & $4^{\circ} 31^{\prime} 06.9^{\prime \prime}$ \\
\hline Point 2 & 50.22 & 747’13.1" & $4^{\circ} 31^{\prime} 07.1^{\prime \prime}$ \\
\hline Point 3 & 36.27 & $7^{\circ} 47^{\prime} 13.1^{\prime \prime}$ & $4^{\circ} 31^{\prime} 06.5^{\prime \prime}$ \\
\hline Point 4 & 78.12 & 747'13.3” & $4^{\circ} 31^{\prime} 04.8^{\prime \prime}$ \\
\hline Point 5 & 55.80 & $7^{\circ} 47^{\prime} 13.5^{\prime \prime}$ & $4^{\circ} 31^{\prime} 0.41^{\prime \prime}$ \\
\hline Control point & 37.66 & 747'13.2” & $4^{\circ} 31^{\prime} 02.7^{\prime \prime}$ \\
\hline
\end{tabular}
to $4{ }^{\circ} 31^{\prime} 07$. ' $^{\prime}$ and latitudes 7047 '13.1" to $7047^{\prime} 13.7$ " while the land elevation is within $37.66 \mathrm{~m}$ to $78.12 \mathrm{~m}$ above sea level.

Table 1: Geographical Locations of the Sampling Sites in Osogbo

Source: Authors' field Survey, (2014 to 2015)

\section{Physicochemical Analysis}

The results of physicochemical parameters of the effluent samples collected in wet and dry season around the lubricating oil company are presented in Table 2 and 3. The temperature for wet season ranged between (27.60 to 28.80$)$ $\circ \mathrm{C}$ with mean \pm standard deviation $(27.87 \pm 0.82$ to $28.48 \pm 0.44) \circ \mathrm{C}$ and dry season ranged from (27.40 to 29.86$) \circ \mathrm{C}$ with mean \pm standard deviation $(27.75 \pm 0.33$ to $29.70 \pm 0.20){ }^{\circ} \mathrm{C}$ respectively. There was fluctuation in the values measured in wet season. Dry season had slightly higher values compare to wet season values. Fluctuation in temperature values in wet season could be as a result of the quantity of effluent entering the soil because of leaching and changes in weather forecast of the day. High temperature value in dry season is an indicative of seasonal influence by heat on the sampling site. 
The recommended limit for no risk according to WHO [13] is $30 \mathrm{O}$. Based on this guidelines, the temperature of the effluents in both wet and dry season does not appear to pose any treat to homeostatic balance of the receiving water bodies, which corroborate the report of [14].

$\mathrm{pH}$ values measured for all sampling points in wet season $(7.35 \pm 0.51$ to $7.78 \pm 0.11)$ is an indicative of basic environment. Same but lower range of measurement was recorded also for dry season. The values measured in both seasons were within World Health Organization standards (WHO) set limit, 6.5 - 9.6 of wastewater which must be discharged into the sea or environment [13].

High electrical conductivity values were obtained in wet season at all the sampling points; this may be due to water run-off that brings in lots of dissolved conducting minerals. High conductivity at the sampling points indicates the mixing of sewage at the sites [15].

Total dissolved solid measured in wet season ranged from (109.80 to 160.02$) \mathrm{mg} / \mathrm{L}$ and overall Mean $\pm \mathrm{SD}$ ranged from $(112.54 \pm 2.72$ to $155.08 \pm 4.96) \mathrm{mg} / \mathrm{L}$ per sampling point. Also, the value recorded in dry season ranged from (56.76 to 104.11$) \mathrm{mg} / \mathrm{L}$ and overall Mean \pm SD ranged from $(58.18 \pm 1.73$ to $101.34 \pm 2.82) \mathrm{mg} / \mathrm{L}$ per sampling point. The values measured in wet season at all the points were very high compared to that of dry season, indicating influx by runoff on the concentration and the values for both seasons were within the permissible limit of $500 \mathrm{mg} / \mathrm{L} \mathrm{WHO} \mathrm{[13].}$

Table 3 presents the Dissolved Oxygen (DO) and Biochemical Oxygen Demand (BOD) measured in both wet and dry season. DO in wet season ranged from $2.87 \mathrm{mg} / \mathrm{L}$ to $6.03 \mathrm{mg} / \mathrm{L}$, overall mean for the sampling points ranged from $(3.07 \pm 0.70) \mathrm{mg} / \mathrm{L}$ to $(5.96 \pm 0.08) \mathrm{mg} / \mathrm{L}$ and $2.58 \mathrm{mg} / \mathrm{L}$ to $7.01 \mathrm{mg} / \mathrm{L}$, overall mean from $2.78 \pm 0.22$ to $(6.96 \pm 0.07) \mathrm{mg} / \mathrm{L}$ for dry season. Dissolve oxygen values recorded for various sampling points in wet season were a bit higher than that of dry season which indicates lower pollution level in the sampling points. Low dissolved oxygen could be attributed to the less fresh water inputs into the study area, higher temperature and salinity as a result of higher evaporation [16].

The BOD according to WHO standard permissible limit is $10 \mathrm{mg} / \mathrm{L}$, high level biochemical oxygen demand were recorded for all samples in wet season, this could be as a result of heavy discharged of the company waste water and other environmental organic contaminants by downpour in the area. In dry season only point $1(11.04 \pm 0.12) \mathrm{mg} / \mathrm{L}$ and point $2(13.00 \pm 0.06) \mathrm{mg} / \mathrm{L}$ showed high biochemical oxygen demand values which is an indication of their closeness to point source and more importantly, an evident that the waste water discharged was polluted.

The results of correlation coefficients ' $r$ ' (Table 4) at 0.01 and 0.05 significant level obtained in both wet and dry season have the same correlation trend, temperature showed a positive correlation between EC, TDS, BOD and negative correlation between DO. It showed the important role of temperature in physical and chemical parameters in the ecosystem. Electrical conductivity showed a positive correlation between TDS and BOD but negative correlation with DO in both seasons. Total dissolved solid is positively corrected with BOD but negatively correlated with DO.

Statistical analysis using ANOVA showed at $(p \leq 0.05)$ that there was no significant difference between the five sampling site for all the parameters analyzed in both seasons 
Table 2: Physicochemical Parameters of Effluents Collected Around the Lubricating Oil Company in Osogbo

\begin{tabular}{|c|c|c|c|c|c|c|c|c|c|c|c|c|c|c|c|c|}
\hline \multicolumn{9}{|c|}{ Temperature $\left({ }^{\circ} \mathrm{C}\right)$} & \multicolumn{8}{|c|}{$\mathrm{pH}$} \\
\hline \multicolumn{5}{|c|}{ Wet Season } & \multicolumn{4}{|c|}{ Dry Season } & \multicolumn{4}{|c|}{ Wet Season } & \multicolumn{4}{|c|}{ Dry Season } \\
\hline Sites & Aug & Sept & Oct & Mean \pm SD & Dec & Jan & Feb & Mean \pm SD & Aug & Sept & Oct & Mean \pm SD & $\mathrm{Dec}$ & Jan & Feb & Mean \pm SD \\
\hline PT 1 & 28.40 & 27.68 & 28.36 & $28.15 \pm 0.41$ & 29.86 & 29.48 & 29.77 & $29.70 \pm 0.20$ & 7.21 & 7.34 & 7.50 & $7.35 \pm 0.51$ & 6.89 & 7.48 & 7.66 & $7.34 \pm 0.40$ \\
\hline PT 2 & 27.60 & 27.72 & 28.30 & $27.87 \pm 0.82$ & 29.60 & 29.81 & 29.58 & $29.66 \pm 0.13$ & 7.60 & 7.72 & 7.60 & $7.64 \pm 0.07$ & 7.40 & 7.60 & 7.57 & $7.52 \pm 0.12$ \\
\hline PT 3 & 28.31 & 28.74 & 27.98 & $28.34 \pm 0.30$ & 29.08 & 29.13 & 29.20 & $29.14 \pm 0.06$ & 7.87 & 7.74 & 7.50 & $7.70 \pm 0.06$ & 7.88 & 7.68 & 7.76 & $7.77 \pm 0.10$ \\
\hline PT 4 & 28.80 & 27.97 & 28.66 & $28.48 \pm 0.44$ & 27.82 & 28.30 & 29.00 & $28.37 \pm 0.59$ & 7.80 & 7.66 & 7.88 & $7.78 \pm 0.11$ & 6.98 & 7.23 & 7.48 & $7.23 \pm 0.25$ \\
\hline PT 5 & 28.30 & 28.45 & 28.65 & $28.47 \pm 0.18$ & 27.40 & 28.06 & 27.80 & $27.75 \pm 0.33$ & 7.30 & 7.45 & 7.50 & $7.42 \pm 0.10$ & 7.31 & 7.56 & 7.46 & $7.44 \pm 0.13$ \\
\hline WHO* & \multicolumn{8}{|l|}{30.00} & \multicolumn{8}{|c|}{$6.50-9.60$} \\
\hline \multicolumn{9}{|c|}{$\mathrm{EC}\left(\mu \mathrm{scm}^{-1}\right)$} & \multicolumn{8}{|c|}{$\mathrm{TDS}(\mathrm{mg} / \mathrm{L})$} \\
\hline \multicolumn{5}{|c|}{ Wet Season } & \multicolumn{4}{|c|}{ Dry Season } & \multicolumn{4}{|c|}{ Wet Season } & \multicolumn{4}{|c|}{ Dry Season } \\
\hline Sites & Aug & Sept & Oct & Mean \pm SD & Dec & Jan & Feb & Mean \pm SD & Aug & Sept & Oct & Mean \pm SD & $\mathrm{Dec}$ & Jan & Feb & Mean \pm SD \\
\hline PT 1 & 203.93 & 210.89 & 206.00 & $206.94 \pm 3.57$ & 129.45 & 137.94 & 142.40 & $136.60 \pm 6.58$ & 109.8 & 115.24 & 112.57 & $112.54 \pm 2.72$ & 80.28 & 84.34 & 89.00 & $84.54 \pm 4.36$ \\
\hline PT 2 & 227.75 & 220.20 & 236.07 & $228.01 \pm 7.94$ & 164.27 & 158.57 & 166.58 & $163.14 \pm 4.12$ & 122.27 & 120.33 & 129.00 & $123.87 \pm 4.55$ & 101.42 & 98.48 & 104.11 & $\begin{array}{l}101.34 \\
\pm 2.82 \\
\end{array}$ \\
\hline PT 3 & 240.47 & 238.30 & 250.27 & $243.01 \pm 6.38$ & 98.35 & 109.68 & 103.82 & $102.28 \pm 5.67$ & 135.23 & 130.22 & 136.76 & $134.07 \pm 3.42$ & 60.78 & 68.55 & 64.89 & $64.74 \pm 3.89$ \\
\hline PT 4 & 245.05 & 256.62 & 259.64 & $253.77 \pm 7.70$ & 106.45 & 111.84 & 115.20 & $111.16 \pm 4.41$ & 135.00 & 140.23 & 141.88 & $138.78 \pm 3.59$ & 66.80 & 69.90 & 72.00 & $69.57 \pm 2.62$ \\
\hline PT 5 & 277.68 & 283.87 & 292.84 & $284.80 \pm 7.62$ & 98.88 & 96.28 & 92.27 & $95.81 \pm 3.33$ & 150.10 & 155.12 & 160.02 & $155.08 \pm 4.96$ & 56.76 & 60.11 & 57.67 & $58.18 \pm 1.73$ \\
\hline WHO* & 500.00 & & & & & & & & 500.00 & & & & & & & \\
\hline
\end{tabular}

EC = Electrical conductivity, TDS = Total dissolve solid

Mean $\pm \mathrm{SD}=$ Mean of three replicate measurement. $\mathrm{WHO}^{*}=$ World health organization permissible limit

Source: Authors' field Survey, (2014 to 2015) 
Table 3: Physicochemical Parameters of Effluents Collected Around the Lubricating Oil Company in Osogbo

\begin{tabular}{|c|c|c|c|c|c|c|c|c|c|c|c|c|c|c|c|c|}
\hline \multicolumn{9}{|c|}{ DO (mg/L) } & \multicolumn{8}{|c|}{$\mathrm{BOD}(\mathrm{mg} / \mathrm{L})$} \\
\hline \multicolumn{5}{|c|}{ Wet Season } & \multicolumn{4}{|c|}{ Dry Season } & \multicolumn{4}{|c|}{ Wet Season } & \multicolumn{4}{|c|}{ Dry Season } \\
\hline Sites & Aug & Sept & Oct & Mean \pm SD & Dec & Jan & Feb & Mean \pm SD & Aug & Sept & Oct & Mean \pm SD & Dec & Jan & Feb & Mean \pm SD \\
\hline PT 1 & 6.03 & 5.87 & 5.98 & $5.96 \pm 0.08$ & 3.20 & 4.00 & 3.48 & $3.56 \pm 0.41$ & 8.09 & 7.45 & 7.11 & $7.55 \pm 0.50$ & 11.11 & 10.9 & 11.05 & $11.04 \pm 0.12$ \\
\hline PT 2 & 4.83 & 5.67 & 5.99 & $5.50 \pm 0.60$ & 2.58 & 3.01 & 2.76 & $2.78 \pm 0.22$ & 10.34 & 10.01 & 9.98 & $10.11 \pm 0.20$ & 13.02 & 12.9 & 13.04 & $13.00 \pm 0.06$ \\
\hline PT 3 & 4.70 & 5.02 & 4.47 & $4.73 \pm 0.28$ & 5.23 & 5.38 & 4.98 & $5.20 \pm 0.20$ & 11.27 & 10.88 & 10.45 & $10.87 \pm 0.41$ & 7.04 & 6.98 & 6.97 & $7.00 \pm 0.19$ \\
\hline PT 4 & 3.89 & 4.02 & 4.12 & $4.01 \pm 0.12$ & 4.15 & 4.55 & 4.35 & $4.35 \pm 0.20$ & 11.70 & 11.02 & 11.78 & $11.50 \pm 0.42$ & 9.23 & 8.88 & 8.67 & $8.93 \pm 0.28$ \\
\hline PT 5 & 3.23 & 2.87 & 3.12 & $3.07 \pm 0.18$ & 7.00 & 6.88 & 7.01 & $6.96 \pm 0.07$ & 14.20 & 13.03 & 13.67 & $13.63 \pm 0.59$ & 5.00 & 5.23 & 5.05 & $5.09 \pm 0.12$ \\
\hline WHO* & \multicolumn{8}{|c|}{10.00} & \multicolumn{8}{|c|}{10.00} \\
\hline
\end{tabular}

DO = Dissolve oxygen, BOD = Biochemical oxygen demand

Mean \pm SD $=$ Mean of three replicate measurement; $\mathrm{WHO} *=$ World health organization permissible limit

Source: Authors' field Survey, (2014 to 2015)

Table 4: Pearson's Correlation Coefficient ( $r$ ) for Different Physicochemical Parameters in Wet and Dry Season

\begin{tabular}{|c|c|c|c|c|c|c|c|c|c|c|c|c|}
\hline & \multicolumn{6}{|c|}{ Wet Season } & \multicolumn{6}{|c|}{ Dry Season } \\
\hline & $\operatorname{Temp}\left({ }^{\circ} \mathrm{C}\right)$ & $\mathrm{pH}$ & $\begin{array}{c}\mathrm{EC}(\mu \mathrm{S} \\
\left.\mathrm{cm}^{-1}\right)\end{array}$ & $\mathrm{TDS}(\mathrm{mg} / \mathrm{L})$ & $\mathrm{DO}(\mathrm{mg} / \mathrm{L})$ & $\mathrm{BOD}(\mathrm{mg} / \mathrm{L})$ & $\operatorname{Temp}\left({ }^{\circ} \mathrm{C}\right)$ & $\mathrm{pH}$ & $\mathrm{EC}\left(\mu \mathrm{S} \mathrm{cm} \mathrm{cm}^{-1}\right)$ & $\mathrm{TDS}(\mathrm{mg} / \mathrm{L})$ & $\mathrm{DO}(\mathrm{mg} / \mathrm{L})$ & $\mathrm{BOD}(\mathrm{mg} / \mathrm{L})$ \\
\hline $\operatorname{Temp}\left({ }^{\circ} \mathrm{C}\right)$ & 1 & & & & & & 1 & & & & & \\
\hline $\mathrm{pH}$ & 0.116 & 1 & & & & & 0.243 & 1 & & & & \\
\hline $\left.\mathrm{EC}(\mu \mathrm{S} \mathrm{cm})^{-1}\right)$ & 0.702 & 0.133 & 1 & & & & 0.785 & -0.105 & 1 & & & \\
\hline $\mathrm{TDS}(\mathrm{mg} / \mathrm{L})$ & 0.719 & 0.161 & 0.999 & 1 & & & 0.806 & -0.082 & 0.998 & 1 & & \\
\hline $\mathrm{DO}(\mathrm{mg} / \mathrm{L})$ & -0.794 & -0.136 & -0.987 & -0.987 & 1 & & -0.851 & 0.161 & -0.898 & -0.916 & 1 & \\
\hline $\mathrm{BOD}(\mathrm{mg} / \mathrm{L})$ & 0.61 & 0.246 & 0.986 & 0.986 & 0.955 & 1 & 0.819 & -0.206 & 0.964 & 0.972 & -0.979 & 1 \\
\hline
\end{tabular}

KEY: Temp = Temperature, EC = Electrical conductivity, TDS = Total dissolve solid, DO = Dissolve oxygen,

$\mathrm{BOD}=$ Biochemical oxygen demand.

Correlating rating; $>0.90=$ Very strong, $0.80-0.90=$ Strong, $0.50-0.70=$ Moderate, $0.1-0.40=$ Weak

Source: Authors' field Survey, (2014 to 2015) 


\section{Levels of Total Heavy Metals in the soil Sediment Samples}

The mean total levels of heavy metals $(\mu \mathrm{g} / \mathrm{g})$ in the sediment samples collected in wet season (August, September, October) at sampling points followed the same order, $\mathrm{Mn}>\mathrm{Ni}>\mathrm{Co}>\mathrm{Cd}>\mathrm{Pb}$ and in dry season(December, January, February) there was similar pattern with slight variation at point as shown in Table 5 and appendix in dry season the order were : Point 1: $\mathrm{Mn}>\mathrm{Co}>\mathrm{Ni}>\mathrm{Cd}>\mathrm{Pb}$, Point 2: $\mathrm{Mn}>\mathrm{Ni}>\mathrm{Cd}>\mathrm{Co}>\mathrm{Pb}$, Point 3: $\mathrm{Mn}>\mathrm{Ni}>\mathrm{Cd}>\mathrm{Co}>\mathrm{Pb}$, Point 4: $\mathrm{Mn}>\mathrm{Ni}>\mathrm{Co}>\mathrm{Cd}>\mathrm{Pb}$. Point $5: \mathrm{Mn}>\mathrm{Co}>\mathrm{Ni}>\mathrm{Cd}>\mathrm{Pb}$. Generally, the total metal concentration level found in the sediment samples collected in dry season were very high, this could be attributed the particulate effects that is capable of increasing heavy metal content by aerial deposition [17]. 
Table 5: The Mean Concentration of the Metal $(\mu \mathrm{g} / \mathrm{g})$ in the Sediments Collected in Wet and Dry Season

\begin{tabular}{|c|c|c|c|c|c|c|c|c|c|c|}
\hline & \multicolumn{5}{|c|}{ Wet Season } & \multicolumn{5}{|c|}{ Dry Season } \\
\hline & $\mathrm{Mn}$ & $\mathrm{Ni}$ & Co & $\mathrm{Cd}$ & $\mathrm{Pb}$ & $\mathrm{Mn}$ & $\mathrm{Ni}$ & Co & $\mathrm{Cd}$ & $\mathrm{Pb}$ \\
\hline PT1 & $58.00 \pm 3.29$ & $17.00 \pm 1.74$ & $15.74 \pm 0.96$ & $14.55 \pm 2.28$ & $3.88 \pm 1.44$ & $105.45 \pm 7.90$ & $21.81 \pm 2.28$ & $22.87 \pm 2.48$ & $19.04 \pm 0.91$ & $8.10 \pm 2.42$ \\
\hline PT2 & $72.00 \pm 1.65$ & $15.01 \pm 1.14$ & $14.44 \pm 0.53$ & $12.12 \pm 1.08$ & $5.00 \pm 0.98$ & $154.22 \pm 1.72$ & $28.41 \pm 1.49$ & $20.02 \pm 1.13$ & $21.94 \pm 1.65$ & $10.22 \pm 1.15$ \\
\hline PT3 & $63.90 \pm 4.53$ & $17.70 \pm 1.22$ & $18.45 \pm 1.71$ & $15.30 \pm 2.17$ & $5.28 \pm 1.16$ & $114.50 \pm 16.81$ & $16.20 \pm 1.86$ & $13.67 \pm 1.78$ & $13.79 \pm 1.57$ & $6.55 \pm 2.32$ \\
\hline PT4 & $86.65 \pm 6.59$ & $19.40 \pm 1.34$ & $18.89 \pm 2.24$ & $14.90 \pm 1.87$ & $6.22 \pm 0.89$ & $118.00 \pm 2.07$ & $19.32 \pm 1.72$ & $18.11 \pm 1.95$ & $16.48 \pm 0.72$ & $4.89 \pm 1.39$ \\
\hline PT5 & $101.12 \pm 2.61$ & $23.48 \pm 2.01$ & $21.28 \pm 1.09$ & $14.00 \pm 1.48$ & $9.15 \pm 1.69$ & $99.53 \pm 3.60$ & $16.44 \pm 1.91$ & $17.04 \pm 0.95$ & $16.21 \pm 1.90$ & $4.48 \pm 1.66$ \\
\hline Mean \pm SD & $76.33 \pm 3.73$ & $18.52 \pm 1.49$ & $17.76 \pm 1.31$ & $14.17 \pm 1.78$ & $5.91 \pm 1.23$ & $118.34 \pm 6.42$ & $20.44 \pm 1.85$ & $18.34 \pm 1.66$ & $17.49 \pm 1.35$ & $6.85 \pm 1.79$ \\
\hline $\mathrm{CV}(\%)$ & 4.89 & 8.05 & 7.38 & 12.56 & 20.81 & 5.43 & 9.05 & 9.05 & 7.72 & 26.13 \\
\hline Control & 12.4 & 4.13 & 2.34 & 5.15 & 2.88 & 16.67 & 5.85 & 3.24 & 4.4 & 3.13 \\
\hline PL & $460-1110$ & - & - & $0.6-10.00$ & $31-250$ & $460-1110$ & - & - & $0.6-10.00$ & $31-250$ \\
\hline
\end{tabular}

Key: Permissible Limit ( $\mu \mathrm{g} / \mathrm{g}$ dry wt.), according to Persaud, et al., 1993.

Mean $\pm \mathrm{SD}=$ Mean of three replicate measurements.

Source: Authors' field Survey, (2014 to 2015) 


\section{Contamination Assessment Results of Sediment Samples}

The result of the calculated values according to equation 1 for geoaccumulation index (I-geo) in the sediment samples collected in both wet and dry season is shown in Table 6. Based on contamination classification kumar and edward [7], all metals shows I-geo values that is less than zero in all the sampling points except Cd. It implies that all samples were practically uncontaminated with $\mathrm{Mn}, \mathrm{Ni}, \mathrm{Co}$ and $\mathrm{Pb}$ which suggests that $\mathrm{Mn}, \mathrm{Ni}$, Co and $\mathrm{Pb}$ input in these sediments is associated with the parent material that formed the soil or other natural or small anthropogenic non-point sources. A similar spatial distribution of $\mathrm{Ni}$ in soil around an industrial facility in Mexico has been reported to be attributed to input from parent rocks in the surrounding [18]. However, the high level of $\mathrm{Cd}$ in wet and dry Season suggested that the source could be due to effluents, raw materials used in the production from the industry. Total metal concentration in the sediment except $\mathrm{Cd}$ was found to be higher than the values in the control samples and the permissible limits in the sediment by Persaud, et al. [19]. This further strengthens the fact that Cd pollution is from the effluents

Table 6: Assessment of Metals Contamination Using Geo-accumulation Index (I-geo) for Wet and Dry Season

\begin{tabular}{|c|c|c|c|c|c|c|c|}
\hline & & \multicolumn{4}{|c|}{ Wet Season } & \multicolumn{2}{|c|}{ Dry Season } \\
\hline & Metal & $\begin{array}{c}\text { Mean Conc. Of } \\
\text { metal }(\mu \mathrm{g} / \mathrm{g})\end{array}$ & $\begin{array}{c}\text { Geochemical } \\
\text { background (Bn) }\end{array}$ & $\begin{array}{c}\text { Background } \\
\text { matrix }\end{array}$ & I-geo & $\begin{array}{c}\text { Mean Conc. Of } \\
\text { metal }(\mu \mathrm{g} / \mathrm{g})\end{array}$ & I-geo \\
\hline \multirow{5}{*}{ PT1 } & Mn & 58.00 & 320.00 & 1.50 & -3.05 & 105.45 & -2.19 \\
\hline & $\mathrm{Ni}$ & 17.00 & 17.00 & 1.50 & -0.59 & 21.81 & -0.23 \\
\hline & $\mathrm{Co}$ & 15.74 & 10.00 & 1.50 & 0.07 & 22.87 & 0.61 \\
\hline & $\mathrm{Cd}$ & 14.55 & 0.30 & 1.50 & 5.02 & 19.04 & 5.40 \\
\hline & $\mathrm{Pb}$ & 3.88 & 17.00 & 1.50 & -2.72 & 8.10 & -1.65 \\
\hline \multirow{5}{*}{ PT2 } & $\mathrm{Mn}$ & 72.00 & 320.00 & 1.50 & -2.24 & 154.22 & -1.64 \\
\hline & $\mathrm{Ni}$ & 15.01 & 17.00 & 1.50 & -0.76 & 28.41 & 0.16 \\
\hline & $\mathrm{Co}$ & 14.44 & 10.00 & 1.50 & -0.05 & 20.02 & 0.42 \\
\hline & $\mathrm{Cd}$ & 12.12 & 0.30 & 1.50 & 4.75 & 21.94 & 5.61 \\
\hline & $\mathrm{Pb}$ & 5.00 & 17.00 & 1.50 & -2.35 & 10.22 & -1.32 \\
\hline \multirow{5}{*}{ PT3 } & $\mathrm{Mn}$ & 63.90 & 320.00 & 1.50 & -2.91 & 114.5 & -2.07 \\
\hline & $\mathrm{Ni}$ & 17.70 & 17.00 & 1.50 & -0.53 & 16.20 & -0.65 \\
\hline & $\mathrm{Co}$ & 18.45 & 10.00 & 1.50 & 0.30 & 13.67 & -0.13 \\
\hline & $\mathrm{Cd}$ & 15.30 & 0.30 & 1.50 & 5.09 & 13.79 & 4.94 \\
\hline & $\mathrm{Pb}$ & 5.28 & 17.00 & 1.50 & -2.27 & 6.55 & -1.96 \\
\hline \multirow{5}{*}{ PT4 } & $\mathrm{Mn}$ & 86.65 & 320.00 & 1.50 & -2.47 & 118 & -2.02 \\
\hline & $\mathrm{Ni}$ & 19.40 & 17.00 & 1.50 & -0.39 & 19.32 & -0.40 \\
\hline & Co & 18.89 & 10.00 & 1.50 & 0.33 & 18.11 & 0.27 \\
\hline & $\mathrm{Cd}$ & 14.90 & 0.30 & 1.50 & 1.52 & 16.48 & 5.20 \\
\hline & $\mathrm{Pb}$ & 6.22 & 17.00 & 1.50 & -2.04 & 4.89 & -2.38 \\
\hline \multirow{5}{*}{ PT5 } & $\mathrm{Mn}$ & 101.12 & 320.00 & 1.50 & -2.25 & 99.53 & -2.27 \\
\hline & $\mathrm{Ni}$ & 23.48 & 17.00 & 1.50 & -0.12 & 16.44 & -0.63 \\
\hline & $\mathrm{Co}$ & 21.28 & 10.00 & 1.50 & 0.50 & 17.04 & 0.18 \\
\hline & $\mathrm{Cd}$ & 14.00 & 0.30 & 1.50 & 4.96 & 16.21 & 5.17 \\
\hline & $\mathrm{Pb}$ & 9.15 & 17.00 & 1.50 & -1.48 & 4.48 & -2.51 \\
\hline
\end{tabular}

Source: Authors' field Survey, (2014 to 2015)

\section{Pollution Loading Index (PLI) of Heavy Metals in the Sediments}

The calculation was done according to the equation 2 introduced by Thomlinson et al. [8] as shown in Table 7. According to, all sampling sites in both wet and dry seasons shows signs of pollution or deterioration of site quality PLI values is greater than 1 . This suggests input from the lubricating oil company or anthropogenic sources. 
Table 7: Pollution load index in sediments in wet and dry season

\begin{tabular}{|l|l|l|}
\hline Site & PLI(Wet season) & PLI(Dry season) \\
\hline PT1 & 1.78 & 1.97 \\
\hline PT2 & 1.28 & 2.35 \\
\hline PT3 & 1.43 & 1.53 \\
\hline PT4 & 1.61 & 1.65 \\
\hline PT5 & 1.88 & 1.48 \\
\hline
\end{tabular}

Source: Authors' field Survey, (2014 to 2015)

\section{Enrichment Factors (EFs)}

The enrichment factor calculated according to equation 3 for the sediment in wet and dry season is shown in Table 8. The EFs in wet and dry season were generally less than 1 for $\mathrm{Mn}$, Co and $\mathrm{Pb}$, which suggest a natural source for these elements in the sediment.

There is minor enrichment for Ni. This implied Ni as catalyst in distillation of crude oil and carried over in the oil lubricant processes. However the sediment is severely enriched with $\mathrm{Cd}$, confirming an effluent pollution source of $\mathrm{Cd}$ in the sampling locations.

Table 8: Enrichment Factor of Sediment during Wet and Dry Season.

\begin{tabular}{|l|l|l|l|l|l||l|l|l|l|l|l|}
\hline & \multicolumn{5}{|c||}{ Wet Season } & \multicolumn{5}{c|}{ Dry Season } \\
\hline Location & $\mathrm{Pb}$ & $\mathrm{Ni}$ & $\mathrm{Cd}$ & $\mathrm{Mn}$ & $\mathrm{Co}$ & $\mathrm{Pb}$ & $\mathrm{Ni}$ & $\mathrm{Cd}$ & $\mathrm{Mn}$ & $\mathrm{Co}$ \\
\hline PT1 & 0.85 & 0.91 & 48.50 & 0.18 & 0.39 & 1.09 & 1.35 & 63.47 & 0.33 & 0.81 \\
\hline PT2 & 0.75 & 0.85 & 40.40 & 0.23 & 0.30 & 1.42 & 1.18 & 73.13 & 0.48 & 1.02 \\
\hline PT3 & 0.89 & 1.09 & 51.00 & 0.20 & 0.53 & 0.81 & 0.80 & 45.97 & 0.36 & 0.66 \\
\hline PT4 & 0.97 & 1.11 & 49.67 & 0.27 & 0.62 & 0.97 & 1.07 & 54.93 & 0.37 & 0.49 \\
\hline PT5 & 1.17 & 1.25 & 46.67 & 0.32 & 0.92 & 0.82 & 1.00 & 54.03 & 0.31 & 0.45 \\
\hline
\end{tabular}

Source: Authors' field Survey, (2014 to 2015)

\section{Cluster Analysis of Metals in the Sediments Collected in Wet and Dry season}

The cluster analysis of heavy metals in the sediment samples in wet and dry season shown in Figure 2. Wet season shows two major chemical associations. The first association shows relationship between $\mathrm{Pb}, \mathrm{Co}, \mathrm{Cd}$, Ni while the second association shows relationship between $\mathrm{Mn}$ and Co which means that they may be from the same source except Mn. This could be as result of the effluents being discharged to the sampling area and lithogenic origin (Mn-Co), although, Co was associated with the first cluster, meaning that, Co contribution is from two major sources: effluents and mother soil. Also, dry season shows two major chemical associations. The first chemical associations include $\mathrm{Mn}$ and Ni while the second associations include $\mathrm{Pb}, \mathrm{Ni}, \mathrm{Cd}$, Co. This implies that they are from the same source except Mn. This also confirmed the lithogenic origin of $\mathrm{Mn}$, but $\mathrm{Ni}$ and $\mathrm{Co}$ are metals in the effluents and soil competing with $\mathrm{Mn}$ as a result of the similar solubility of their salts and probably because they exist in +2 state, which made the solubility pattern of the salts of $\mathrm{Co}$ and $\mathrm{Ni}$ to be the same. 


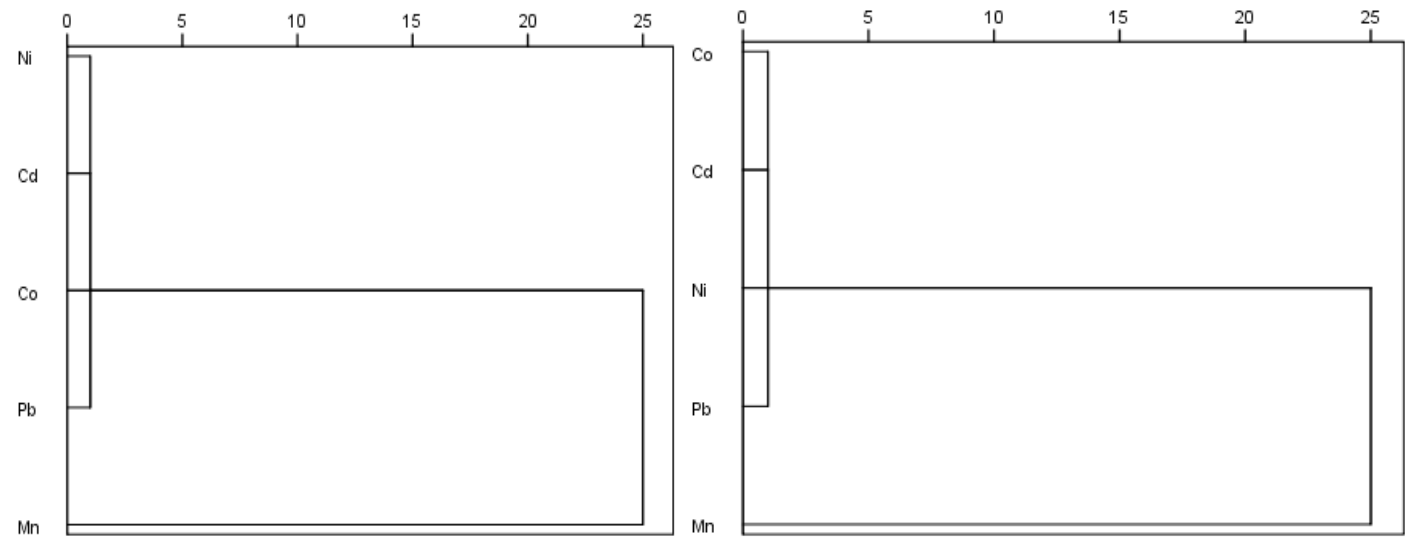

WET SEASON

DRY SEASON

\section{Fig. 2: Dendrogram showing metals trend in sediment in Wet and Dry Seasons}

Statistical analysis using ANOVA showed at $(p \leq 0.05)$ that there was no significant difference between the concentrations of the metals analyzed for in both seasons

\section{CONCLUSION}

This study revealed that the result obtained for determination of physicochemical parameters in wet and dry season were within the permissible limit stipulated by WHO [13]. However, significant pollution was indicated by the high values in BOD in both seasons which were above the safe limit in water. High BOD value obtained in both seasons indicates organic pollution from the company or other anthropogenic source. Statistically, ANOVA analysis showed no significant difference at $p \leq 0.05$ between the parameters obtained in both seasons.

The results, according to geochemical analysis showed that the sediment was polluted with Cd. By calculation, there is minor EFs of $\mathrm{Mn}, \mathrm{Co}, \mathrm{Pb}$ and $\mathrm{Ni}$ in the sediment. However the sediment is severely enriched with $\mathrm{Cd}$. It was obvious that majority of the heavy metal levels measured could be traced to point source input; the lubricating company and other anthropogenic activities around the study area.

Metal analysis in sediment showed a higher concentration value of Mn during wet and dry season. Thus, cluster analysis showed two sources, Mn from parent rock of the soil while other metals ( $\mathrm{Ni}, \mathrm{Co}, \mathrm{Pb}$ and $\mathrm{Cd}$ ) were from the effluents, although, traces of $\mathrm{Co}$ and $\mathrm{Ni}$ could be found in the rock that constituted the soil. In both season, the total metal concentration level found in the sediment samples in dry season were very high, compare to wet season but statistical analysis using ANOVA showed at $(p \leq 0.05)$ that there was no significant difference between concentrations of the metals analyzed for in both seasons. A better method of effluent treatment/management before discharged into the environment would certainly be needed to stop heavy metal pollution. The bioaccumulation and synergetic effects of the metals within the allowable limits may pose risk to vegetation and aquatic environment near this industry.

\section{REFERENCES}

1. Uzoekwe,S. A. and Oghosamire, 2011.The effect of refinery and petrochemical effluent on water quality of Ubeji Creek Warri, Southern Nigeria. Ethiopian J. Environ. Stud. Manag. 4(2), 107 - 116.

2. Lenntech , 2004. Water Treatment and Air Purification. Water Treatment, Published by Lenntech, Rotter-Dam Sewage, Netherlands.

3. Ibeto, C.N. and Okoye,C.O.B. 2010. High Level of Heavy Metals in Blood of the Urban Population in Nigeria. Research journal of Environmental Science. ISSN 1819 - 3412. 4(4):371 - 382.

4. Ibeto, C., Okoye, C., Ofoefule, A. and Uzodinma, E. 2012. Analysis of Environmental Pollutants by Atomic Absorption Spectrophotometry, Macro To Nano Spectroscopy, Dr. Jamal Uddin (Ed.), ISBN: 978-953-51-0664-7, InTech.

5. Ogunfowokan, A. O.,Oyekunle, J. A. O., Olutona, G. O., Atoyebi, A. O., Lawal A. 2013. Speciation Study of Heavy Metals in Water and Sediments from Asunle River of the Obafemi Awolowo University, Ile-Ife Nigeria. International Journal of Environmental Protection.Vol.3 Iss.3, PP6-16.

6. Muller, G. 1979. Index of geoaccumulation in sediments of the Rhine River, Geological Journal, 2: 108-118.

7. Kumar, S. P. and Edward, J.K.P. 2009. Assessment of metal concentration in the sediment cores of Manakudy Estuary, South West Coastal of India, Indian J. Mar. Sci., vol. 38 (2), pp. 235-248, June.

8. Thomlinson, D.,Wilson, J., Harris, C. and Jeffrey, D.1980. Problems in the Assessment of Heavy metal levels in Estuaries and the Formation of a Pollution Index. Helgoland Marine Research, Vol.33, 1- 4, pp.566-575.

9. Turekian, K. K. and Wedepohl, K. H. 1961. Distribution of elements in some major units of the Earth's crust Geological Society American Bulletin. 72: 175-192.

10. Sutherland, R. A. 2000. Bed Sediment Associated Trace Metals in an Urban Stream Oahu. Hawaii. Environ. Geo., 39 (6), 611-627 (17 pages). 
11. Singh, B. R. 1997. Soil Pollution and Contamination in R. Lal (ed.), Methods of Assessment of Degradation, CRC Press, Boca Raton, FL. 279 - 299.

12. Mohiuddin, K. M., Zakir, H. M., Otomo, K.; Sharmin, S.;Shikazono, N. 2010. Geochemical distribution of trace metalpollutants in water and sediments of downstream of an urban river. Int. J. Environ. Sci. Tech., 7 (1), 17-28(12 pages).

13. Jaji, M. O., Bamgbose, O., Odukoya, O. O. and Arowolo, T. A. 2007. Water quality assessment of Ogun River, south west Nigeria. Environ. Monit. Assess., 133 (1-3), 447-482 (36 pages).

14. WHO, 2006. World Health Organization. Guidelines for Drinking Water Quality. FATOT Ed.

15. Hassan, F. M., Saleh, M. M. and Salman, J. M. (2009). A Study of Physicochemical Parameters and Nine Heavy Metals in the Euphrates River, Iraq. E-J. Chem., 7: 685-692. DOI: 10.1155/2010/906837.

16. Jothivel, N. and Paul, V. I. 2014.Comparative Physicochemical profiling of Two Coast of India with Special References to the Pollution Status. International journal of modern Research Reviews, vol. 2, pp 544-553.

17. Pan, Y. P and Wang, Y. S. 2015. Atmospheric Wet and Dry Deposition of Trace Element at 10 Sites in Northern China. Atmospheric Chemistry and Physic. 15, 951-972.

18. Morton-Bermea, O., Herna'ndez-A'Ivarez, E., Lozano, R., Guzma'n Morales, J. and Martínez, G. 2010. Spatial distribution of heavy metals in top soils around the industrial facilities of Cromatos de me'xico, Tultitlan Mexico. Bulletin of Environmental Contamination and Toxicology, 85(5):520-524.

19. Persaud, D., Jaagumagi R. and Hayton, A. 1993. Guidelines for the Protection and Management of Aquatic Sediment Quality in Ontario: Ontario Ministry of the Environment and Energy, August. 
Total Metal Levels $(\mu \mathrm{g} / \mathrm{g})$ in the Sediments Collected in Wet and Dry season

\begin{tabular}{|c|c|c|c|c|c|c|c|c|c|c|c|c|c|c|}
\hline & \multicolumn{7}{|l|}{ Wet Season } & \multicolumn{7}{|c|}{ Dry Season } \\
\hline \multirow{5}{*}{ PT1 } & Month & $\mathrm{Mn}$ & $\mathrm{Ni}$ & Co & $\mathrm{Cd}$ & $\mathrm{Pb}$ & Total burden & Month & $\mathrm{Mn}$ & $\mathrm{Ni}$ & Co & $\mathrm{Cd}$ & $\mathrm{Pb}$ & Total burden \\
\hline & Aug & 57.15 & 15.53 & 14.20 & 12.00 & 3.22 & 102.1 & Dec & 98.98 & 19.18 & 22.31 & 18.21 & 10.04 & 168.72 \\
\hline & Sep & 55.22 & 18.92 & 13.98 & 16.38 & 2.89 & 107.39 & Jan & 103.11 & 23.10 & 25.01 & 20.01 & 8.87 & 180.10 \\
\hline & Oct & 61.63 & 16.55 & 12.44 & 15.26 & 5.53 & 111.41 & Feb & 114.26 & 23.16 & 21.28 & 18.90 & 5.39 & 182.99 \\
\hline & Mean \pm SD & $58.00 \pm 3.29$ & $17.00 \pm 1.74$ & $15.74 \pm 0.96$ & $14.55 \pm 2.28$ & $3.88 \pm 1.44$ & $109.17 \pm 9.71$ & Mean $\pm S D$ & $105.45 \pm 7.90$ & $21.81 \pm 2.28$ & $22.87 \pm 2.48$ & $19.04 \pm 0.91$ & $8.10 \pm 2.42$ & $177.27 \pm 15.99$ \\
\hline \multirow{4}{*}{ PT2 } & Aug & 73.03 & 16.33 & 14.22 & 11.25 & 5.08 & 119.91 & Dec & 150.00 & 27.33 & 18.88 & 21.00 & 10.67 & 227.88 \\
\hline & Sep & 70.10 & 14.39 & 13.22 & 11.78 & 3.98 & 113.47 & Jan & 148.62 & 30.11 & 20.04 & 23.84 & 11.08 & 233.69 \\
\hline & Oct & 72.87 & 14.31 & 13.44 & 13.33 & 5.94 & 119.89 & Feb & 152.04 & 27.80 & 21.14 & 20.98 & 8.91 & 230.87 \\
\hline & Mean \pm SD & $72.00 \pm 1.65$ & $15.01 \pm 1.14$ & $14.44 \pm 0.53$ & $12.12 \pm 1.08$ & $5.00 \pm 0.98$ & $118.57 \pm 5.38$ & Mean $\pm S D$ & $154.22 \pm 1.72$ & $28.41 \pm 1.49$ & $20.02 \pm 1.13$ & $21.94 \pm 1.65$ & $10.22 \pm 1.15$ & $234.81 \pm 7.14$ \\
\hline \multirow{4}{*}{ PT3 } & Aug & 61.87 & 17.12 & 20.15 & 14.23 & 6.62 & 119.99 & Dec & 101.72 & 18.15 & 13.88 & 15.34 & 6.42 & 155.51 \\
\hline & Sep & 69.09 & 19.10 & 18.47 & 17.80 & 4.57 & 129.03 & Jan & 108.24 & 16.00 & 15.33 & 13.82 & 4.30 & 157.69 \\
\hline & Oct & 60.74 & 16.88 & 16.73 & 13.87 & 4.65 & 112.87 & Feb & 133.54 & 14.45 & 11.79 & 12.21 & 8.93 & 180.92 \\
\hline & Mean $\pm S D$ & $63.90 \pm 4.53$ & $17.70 \pm 1.22$ & $18.45 \pm 1.71$ & $15.30 \pm 2.17$ & $5.28 \pm 1.16$ & $120.63 \pm 10.79$ & Mean $\pm S D$ & $114.50 \pm 16.81$ & $16.20 \pm 1.86$ & $13.67 \pm 1.78$ & $13.79 \pm 1.57$ & $6.55 \pm 2.32$ & $164.71 \pm 24.34$ \\
\hline \multirow{4}{*}{ PT4 } & Aug & 80.32 & 17.23 & 18.00 & 13.46 & 7.12 & 136.13 & Dec & 120.10 & 21.23 & 18.01 & 17.26 & 3.33 & 179.93 \\
\hline & Sep & 86.16 & 19.11 & 21.43 & 17.02 & 5.34 & 149.06 & Jan & 115.97 & 17.91 & 16.21 & 16.35 & 5.99 & 172.43 \\
\hline & Oct & 93.47 & 20.86 & 17.23 & 14.22 & 6.20 & 151.98 & Feb & 117.93 & 18.82 & 20.11 & 15.83 & 5.35 & 178.04 \\
\hline & Mean $\pm S D$ & $86.65 \pm 6.59$ & $19.40 \pm 1.34$ & $18.89 \pm 2.24$ & $14.90 \pm 1.87$ & $6.22 \pm 0.89$ & $146.06 \pm 12.93$ & Mean $\pm S D$ & $118.00 \pm 2.07$ & $19.32 \pm 1.72$ & $18.11 \pm 1.95$ & $16.48 \pm 0.72$ & $4.89 \pm 1.39$ & $176.80 \pm 7.85$ \\
\hline \multirow{4}{*}{ PT5 } & Aug & 98.50 & 21.22 & 22.28 & 13.30 & 11.01 & 166.31 & Dec & 96.68 & 15.73 & 16.00 & 18.21 & 6.22 & 152.84 \\
\hline & Sep & 103.72 & 25.07 & 21.45 & 13.00 & 7.87 & 171.11 & Jan & 98.33 & 18.60 & 17.85 & 16.00 & 4.31 & 155.09 \\
\hline & Oct & 101.14 & 24.15 & 20.11 & 15.70 & 8.57 & 169.67 & Feb & 103.58 & 14.98 & 17.26 & 14.43 & 2.91 & 153.16 \\
\hline & Mean $\pm S D$ & $101.12 \pm 2.61$ & $23.48 \pm 2.01$ & $21.28 \pm 1.09$ & $14.00 \pm 1.48$ & $9.15 \pm 1.69$ & $169.03 \pm 8.88$ & Mean $\pm S D$ & $99.53 \pm 3.60$ & $16.44 \pm 1.91$ & $17.04 \pm 0.95$ & $16.21 \pm 1.90$ & $4.48 \pm 1.66$ & $153.70 \pm 10.02$ \\
\hline
\end{tabular}

Mean \pm SD $=$ Mean of three replicate measurement

Source: Authors' field Survey, (2014 to 2015)

Wet season

Dry season

6087 | P a g e

February 2018 